УДК 528.1:528.4

\title{
В. В. РЯБЧІЙ
}

Кафедра геодезії, Національний університет “Львівська політехніка”, вул. С. Бандери, 12, Львів, Україна, 79013 , тел.: +38(056)3730720; ел. пошта: RyabchyV@nmu.org.ua

\section{ПРО ВИКОРИСТАННЯ ЗНІМАЛЬНОЇ МЕРЕЖІ ДЛЯ ГЕОДЕЗИЧНОГО ВСТАНОВЛЕННЯ МЕЖ ЗЕМЕЛЬНОЇ ДІЛЯНКИ}

Мета. Розроблення документації із землеустрою шодо відведення земельних ділянок у населених пунктах України с найбілыш поширеними i затребуваними видами робіт із землеустрою. Для якісного їх виконання під час проектування меж земельної ділянки у містах на сучасному рівні необхідно користуватись актуальними топографічними планами масшттабу 1:500. Для виконання тахеометричного знімання $\mathbf{i}$ геодезичного встановлення (відновлення) меж земельної ділянки створюсться знімальна основа. Проміжок часу між двома видами цих робіт незначний. Також ці роботи можуть здійснюватись одночасно, якшо відведення земельної ділянки виконується на основі фактичного розмішення будівель, споруд, парканів тошо. Тахеометричне знімання і геодезичне встановлення меж виконується згідно з відповідними інструкціями. Вочевидь, шо було 6 раціонально створену планову знімальну мережу для тахеометричного знімання використовувати $\mathrm{i}$ для геодезичного встановлення меж земельної ділянки. Так, постає задача створити одну планову знімальну мережу, яка 6 відповідала вимогам до точності чинних інструкцій шодо виконання вказаних робіт. Методика. Для вирішення наведеної мети виконано аналіз і порівняння вимог всіх чинних інструкцій шодо точності побудови знімальних мереж тахеометричного знімання й інструкцій шодо встановлення (відновлення) меж земельних ділянок у натурі (на місцевості). Також проаналізовані публікації науковців нашюї та іншиих країн шодо цісї проблеми. Систематизовані вимоги до точності прокладання теодолітних ходів, побудови на топографічних планах жорстких контурів, будівель, споруд (наземних $\mathrm{i}$ підземних інженерних комунікацій, шо особливо важливо у містах, де на забудованих територіях їх велика кількість). Результати. На основі аналізу нормативно-правових актів Украйни визначено, шо для тахеометричного знімання допускається спрошене вирівнювання теодолітних ходів без урахування похибок вихідних пунктів. Також допускається висячі теодолітні ходи до чотирьох сторін. Нічого не говориться про обчислення середньої квадратичної похибки точок висячого теодолітного ходу і врахування середніх квадратичних похибок точок основного теодолітного ходу. Встановлено також, шо знімальну основу для тахеометричного знімання недоречно i, взагалі, не можна використовувати для геодезичного встановлення (координування) кутів поворотів меж земельної ділянки, оскільки це не дає можливості визначити координати точок кутів поворотів меж цих земельних ділянок з точністю, яка регламентована чинними нормативно-правовими актами України. Наукова новизна. За результатами виконаних досліджень сучасного стану порушеної проблеми розроблені пропозиції шодо послідовності її вирішення. Запропонований для використання “частково забутий”, класичний метод попереднього розрахунку точності елементів геодезичних мереж, дас можливість індивідуального підходу до розробки методики вимірів у кожному випадку спільного або окремого виконання робіт шодо тахеометричного знімання земельної ділянки і геодезичного встановлення іiі меж. Практична значушість роботи полягас у тому, шо для двох видів робіт буде створюватись одна планова знімальна основа. У результаті цього координати точок кутів поворотів меж земельної ділянки $\mathrm{i}$ відповідно іï плоша будуть обчислюватись 3 точністю, яка відповідас чинним інструкціям, а у разі необхідності ше точніше.

Ключові слова: знімальна мережа; теодолітний хід; тахеометричне знімання; геодезичне встановлення меж земельної ділянки; точність визначення координат.

\section{Вступ}

Для розроблення документації із землеустрою у містах використовують актуальні топографічні плани земельних ділянок масштабу 1:500. Для невеликих за площею земельних ділянок топографічне знімання переважно виконується методом тахеометричного зніман- ня. Для виконання тахеометричного знімання, а потім геодезичного встановлення меж земельних ділянок, створюсться планова знімальна геодезична мережа (висотна знімальна мережа в даній статті не розглядається).

Відповідно до підпункту 1.2.4 Інструкції 3 топографічного знімання у масштабах 1:5000, 
1:2000, 1:1000, 1:500 (ГКНТА-2.04-02-98), затверлженої наказом Головного управління геодезіï, картографії та кадастру при Кабінеті Міністрів України [Інструкція, 1998], “топографічні плани масштабу 1:500 можуть застосовуватись для ведення кадастру населених пунктів". У підпункті 1.1.22 цісї Інструкції [Інструкпія, 1998] наведено, шо "виконувати знімання в містах та селишах міського типу тільки на знімальній основі не дозволяється", а пілпункт 1.5.5 пісї Інструкпії [Інструкпія, 1998] вказує, шо: “знімальні геодезичні мережі $\epsilon$ основою для виконання топографічних знімань усіх масштабів та інших робіт".

Згідно 3 пунктом 2.6 Інструкції про встановлення (вілновлення) меж земельних ділянок в натурі (на місцевості) та їх закріплення межовими знаками, затвердженої наказом Державного комітету України із земельних ресурсів [Інструкція, 2010], для спрошення створення знімальної основи виконавці можуть отримувати відомості про наявні пункти державної геодезичної мережі та геодезичних мереж згушення. Цим підтверджується, шо знімальна основа для встановлення або відновлення меж земельної ділянки повинна бути прив'язана до державної геодезичної мережі.

Також у пункті 3.9 пієї Інструкції [Інструкція, 2010] вказусться, шо місцезнаходження межових знаків підлягас прив'язці до пунктів державної геодезичної мережі”. Тобто треба обов'язково вказувати координати точок кутів поворотів меж земельних ділянок у державній системі координат.

Таким чином створення знімальної основи $\mathrm{C}$ важливим етапом, як для виконання тахеометричного знімання, так і для геодезичного встановлення меж земельних ділянок.

Точність визначення координат точок кутів поворотів земельних ділянок та їхніх плош має важливе значення для ведення Державного земельного кадастру, визначення орендної плати або податку за землю, встановлення меж населених пунктів тошо.

Автори статті [Брынь М., Веселкин П., Калгунов В., 2011] вказують, шо положення меж земельних ділянок доцільно визначати відносно пунктів міської геодезичної мережі зі середніми квалратичними похибками до 5 см.
У статті [Дешевая Д. А., Рябчий В. В., 2013] наведена посліловність дій для розрахунку похибок, яка дас змогу заздалегідь обгрунтувати точність вимірювання кутів і довжин не тільки під час коорлинування точок кутів поворотів меж земельної ділянки, а й в теодолітних ходах.

Автори статті [Доскоч А., Тарнавський В., Літинський В., 2010] вказують, шо оцінка точності абсолютної похибки аналітичного обчислення плоші також повинна враховувати точність геодезичної основи. Крім цього, наведено: “... пункти основи не повинні мати похибок, більших ніж 0,05 м, а ситуапійні подробиці I групи мають бути визначені 3 точністю, не меншою, ніж 0,03 м...".

У статтях [Дутчин М., Грицюк Т., Біда I., Ничвид М., 2015; Дутчин М. М., Грицюк Т. Ю., Ільків Є. Ю., Біда І. В., 2014] досліджується точність планового положення пунктів знімальної основи та межових знаків залежно від необхілної точності визначення плош земельних ділянок. Автори дійшли висновку, що точність планового положення пунктів знімальної основи для забезпечення необхідної точності визначення плош земельних ділянок розміром 500-1000 м у містах республіканського й обласного підпорялкування не повинна перевищувати 1-2 см.

Автори статті [Островський А. Л., Мороз О. І., Тарнавський В. Л., 2007] зазначають, шо [Інструкпія, 1998] потребує оновлення через неточності встановлення допустимих параметрів ходів полігонометрії 4 класу, розрядної полігонометрії, теодолітних, тахеометричних $\mathrm{i}$ мензульних ходів.

У статті [Рябчій В. А., Рябчій В. В., Янкін О. Є., 2010] досліджено питання точності визначення плош земельних ділянок до $1000 \mathrm{~m}^{2}$. Встановлено, що визначати координати точок кутів поворотів меж земельних ділянок хоча $i$ можна точніше, ніж це вказано у Керівному технічному матеріалі "Інвентаризація земель населених пунктів (наземні методи)", затвердженому наказом Головного управління геодезії, картографії та каластру при Кабінеті Міністрів України [Керівний технічний матеріал, 1993], але сьогодні це не зовсім раціонально і доцільно.

Автори статті [Рябчій В. А., Рябчій В. В., 2005] та ін. зауважують, шо під час реконструк- 
ціiі (вілновлення) міських геодезичних мереж необхідно прагнути до скорочення їхніх ступенів, оскільки це зменшуватиме величини похибок вихідних пунктів під час створення знімальних мереж.

У статті [Тревого I., Рябчій В., 2014] зазначено, шо наявні геодезичні мережі міст не відповідають сучасним вимогам і не можуть забезпечити необхілне та якісне виконання геодезичних робіт, особливо, на великих територіях, i передовсім, лля робіт із землеустрою та ведення державного земельного кадастру.

Автори статті [Craig B. A., Wahl J. L., 2003] констатують, шо сучасні геодезичні технології не змінили загальну відповідальність виконавців робіт 3 виконання топографічних $\mathrm{i}$ кадастрових знімань. Тим не менш, впровадження і повсякденне застосування глобальної системи позиціонування та комп'ютерної техніки суттєво змінили способи виконання вимірювань, аналізу й обчислення даних. Стандарти точності шодо виконання топографічних і кадастрових знімань повинні враховувати усі вили каластрових просторових даних $\mathrm{i}$ відповідати стандартам Федерального комітету географічних даних (США) для полегшення обміну даними. Сучасні стандарти точності каластрового знімання є недостатніми і повинні бути змінені, шоб відповідати сучасному стану виконання обстежень земельних ділянок $\mathrm{i}$ враховувати той факт, џо геопросторові дані, пов'язані зі зніманням, тепер є одним 3 його основних результатів.

У Керівництві 3 виконання каластрових знімань [Section 1, 2008 i Section 13, 2014] наведено точність виконання різних геодезичних вимірювань, максимально допустимі значення розбіжностей, обчислених за результатами повторних геодезичних вимірів, точність визначення координат точок кутів поворотів меж земельних ділянок тошо. Усі ці значення наведених величин залежать від місця виконання геодезичних робіт i розташування земельних ділянок в Австралії, а саме: центральна частина міста, комерційна і житлова забудова у межах міста, інша забудова у межах міста, забудова у межах іншого населеного пункту або землі сільськогосподарського призначення.

Стандарт і керівництво 3 виконання кадастрових знімань [Standards and Guidelines, 2001] $€$ керівним документом, шо встановлює мінімально допустимий рівень вілносної точності кадастрових вимірювань під час застосування GPS-технологіï. Відносна точність каластрових вимірювань $\epsilon$ середнім показником вілносної точності координат точки вілносно інших сусідніх точок на рівні достовірності $95 \%$. Про результати виконання усіх кадастрових вимірювань слід повідомляти в Федеральний комітет 3 географічних даних, шоб показати взасмозв'язок каластрової зйомки вілносно національної просторової референцної системи. Метод найменших квалратів або інший множинний аналіз вихідних даних застосовується для отримання середньозваженої величини при перевірці одержаного рівня точності позиціонування.

\section{Мета роботи}

Постас таке питання: "Чи можна використовувати створену планову знімальну мережу тахеометричного знімання для геодезичного встановлення меж земельних ділянок?".

Хоча, на перший погляд, на це просте питання можна дати вілповіль: “Так”, але, як це позначатиметься на точності виконання робіт з геодезичного встановлення меж земельних ділянок i, які водночас будуть отримані середні квалратичні похибки координат точок кутів поворотів?

3 наведеного више виходить мета статті. Відповідно до інструктивних вимог обгрунтувати і зробити висновок про можливість використання знімальної мережі тахеометричного знімання в масштабі 1:500 для геодезичного встановлення меж земельних ділянок.

\section{Методика}

Геодезична планова знімальна мережа у порушеному питанні створюсться для тахеометричного знімання та координування точок кутів поворотів меж земельних ділянок. Під координуванням точок кутів поворотів земельних ділянок мають на увазі геодезичні виміри, які використовуються для обчислення координат точок кутів поворотів меж земельних ділянок.

Розмішення пунктів знімальної мережі визначасться під час обстеження земельної ділянки i прилеглої території, яке виконус сертифікований інженер-геодезист. Розмішення пунктів знімальної мережі повинно бути таким, 
щоб забезпечувалась видимість між іï суміжними пунктами, а лля обчислення коорлинат точок кутів поворотів межі земельної ділянки існувала можливість виконати не тільки необхілні, а й наллишкові виміри.

У підпункті 4.2.10 [Керівний технічний матеріал, 1993] вказується, шо за недостатньої шільності геодезичної основи виконується іi згушення. Вказуються методи i те, шо геодезична основа мас відповідати вимогам зйомки масштабу 1:500. Тобто можна сказати, шо планове обгрунтування для інвентаризації земельних ділянок повинно відповідати вимогам топографічного знімання масштабу 1:500.

Здебільшого в сучасних умовах забудови міст планова знімальна мережа створюється прокладенням теодолітного ходу 3 використанням електронних тахеометрів. Вихілними пунктами можуть бути пункти державної геодезичної мережі або геодезичних мереж згущення, а також окремі пункти, координати яких визначені за допомогою GNSS приймачів.

Згілно 3 даними підпункту 5.1.14 (табл. 11a) Інструктії [Інструктія, 1998] допустима довжина теодолітного ходу для масштабу 1:500 не повинна бути більше 2 км, а кількість сторін не перевишувати 20. Також у цьому пункті вказується, шо “на забудованій території довжини сторін у теодолітному ході мають бути в межах від 20 м до 1000 м, а на незабудованих територіях від 40 м до 1500 м.

Згідно 3 підпунктом 4.1 .2 Інструкції [Інструкція, 1998] в полігонометрії 4 класу, 1 і 2 розрядів проклалання висячих ходів не дозволясться. А в теодолітних ходах, для тахеометричного знімання висячі ходи допускаються (підпункт 5.1.17 цієї Інструкції [Інструкція, 1998]). Кількість сторін висячого ходу на незабудованій території мас бути не більше ніж три, а на забудованій - не більше від чотирьох. Згілно 3 пілпунктом 5.1.17 Інструкції [Інструкпія, 1998] довжини висячих ходів не повинні перевишувати величин, шо вказані в табл. 12 . Тобто, у містах під час тахеометричного знімання масштабу 1:500 на забудованій території висячий теодолітний хід може мати чотири сторони, а їх довжини можуть бути від 20 м до 500 м.

Оскільки потім точки висячого теодолітного ходу можна використовувати для коорди- нування точок кутів поворотів меж земельних ділянок, то 3 якими середніми квалратичними похибками отримуються координати точок висячого теодолітного ходу?

Про це у підпункті 5.1 .3 Інструктії [Інструкція, 1998] вказується: "граничні похибки $\Delta_{2 p}$ положення пунктів планової знімальної мережі відносно пунктів державної геодезичної мережі та геодезичних мереж згушення не повинні перевипувати на відкритій місцевості та на забудованій території 0,2 мм у масштабі плану і 0,3 мм - на місцевості, шо закрита деревами та чагарниками". Для топографічного плану масштабу 1:500 гранична похибка положення пунктів планової знімальної мережі відносно пунктів державної геодезичної мережі та геодезичних мереж згущення становить $\Delta_{z p}=0,1 \mathrm{~m}$ або $\Delta_{2 p}=0,15 \mathrm{M}$, а враховуючи вимоги підпункту 1.1.16 цісї Інструкції [Інструкція, 1998] середня квадратична похибка $m=0,125$ м або $m=0,188$ м.

Хоча кількість сторін у висячому теодолітному ході не більше ніж чотири, але за рівності умов вимірів для кожної точки такого ходу похибка положення четвертої точки буде у два рази більше, ніж похибка першої. Вочевиль, це може відповідати точності тахеометричного знімання, але шодо точності геодезичного встановлення або відновлення меж земельної ділянки така кількість сторін висячого теодолітного ходу не підходить.

У пілпункті 5.1.7 Інструкції [Інструкція, 1998] вказується: “зрівнювання знімальної основи виконують спрошеними способами. Обчислення висячих ходів виконують з пунктів опорних геодезичних мереж та точок теодолітних ходів 1 i 2 порядків". Тобто цим пілпунктом визначається, як обчислювати координати точок висячих теодолітних ходів. Середні квалратичні похибки вихідних пунктів (точок) можна не враховувати.

Згілно 3 пунктом 6.33 Інструкції топографічного знімання у масштабах 1:5000, $1: 2000,1: 1000,1: 500$ [Інструктія, 1998] до каталогу коорлинат пунктів значення координат заносять 3 точністю 0,001 м, лиректійні кути до 0,1 ", довжин ліній - до 0,001 м. Така точність запису вказаних величин геодезичних мереж може забезпечити необхідну точність визначення координат точок кутів поворотів 
меж земельної ділянки згідно з Інструкпією про встановлення (вілновлення) меж земельних ділянок в натурі (на місцевості) та їх закріплення межовими знаками [Інструкція, 2010]. Але відповідно до пункту 6.33 Інструкції [Інструкція, 1998] координати пунктів знімальної мережі записують у каталоги з точністю до 0,1 м. Тобто, якшо користуватись такими каталогами, то тільки гранична похибка округлення може сягати 0,05 м.

У пілпункті 7.4.11 Інструкції [Інструкція, 1998] вказується, шо координати і висоти тахеометричних (теодолітних) ходів обчислюються 3 точністю до $0,01 \mathrm{M}$.

Відповідно до пункту 6.18 Інструкпііі [Інструкпія, 1998] зміни координат раніше визначених пунктів і нового зрівнювання не повинні перевишувати 0,10 м. Якшо зміни координат перевипують 0,10 м і мають один знак, можна змінити значення координат вихілних пунктів на постійну величину. Усі наслілки цњого впровадження зараз не обговорюються, вони добре відомі читачеві. Але наведемо тільки один. Буде добре, якшо раніше визначені такі координати не використовувались лля геодезичного встановлення меж земельних ділянок.

Згідно 3 підпунктом 1.1 .16 Інструкції [Інструкція, 1998] у взаємному положенні на топографічному плані середні похибки точок найближчих контурів (капітальних споруд, будинків тощо) не повинні перевишувати 0,4 мм. Для переходу від середніх похибок $\Delta$ до середніх квалратичних похибок $m$ застосовусться коефіціснт 1,25, тобто $m=1,25 \Delta$. Для топографічного плану масштабу 1:500 середня похибка нанесення на план якоїсь капітальної споруди, стіни будинку або інше може дорівнювати $\Delta=0,20 \mathrm{M}$, а середня квалратична похибка $-m=0,25$ м. Ці вимоги стосуються як до споруд, так $\mathrm{i}$ до наземних $\mathrm{i}$ підземних інженерних комунікапій.

У пункті 19 Порядку проведення інвентаризапії земель, затверлженому постановою Кабінету Міністрів України [Порядок, 2012], вказується, шо для забезпечення необхілної точності вілображення прийнятої облікової одиниці площі гранична похибка поворотних точок меж земельних ділянок відносно найближчих пунктів державної геодезичної мережі не повинна перевишувати:

- у м. Кисві, Севастополі та інших містах обласного підпорядкування - 0,1 м;
- в інших містах та селишах - 0,2 м;

- у селах - 0,3 м;

- за межами населених пунктів - 0,5 м.

Тобто для міст обласного підпорядкування допустима середня квалратична похибка положення кутів поворотів меж земельної ділянки не повинна перевишувати 0,1 м, а допустима мінімальна середня квадратична похибка положення планової знімальної мережі для топографічного (тахеометричного) знімання дорівнюе $0,125 \mathrm{M}$.

Також у пункті 20 цього Порялку [Порядок, 2012] вказується, шо під час проведення інвентаризапії земель плоца земельної ділянки зазначасться до $1 \mathrm{~m}^{2}$ з урахуванням граничної похибки масштабу плану у разі, коли координати точки кута повороту межі визначаються 3 точністю до $0,01 \mathrm{M}$.

У зв'язку 3 цим постає питання. Коли координати точки кута повороту межі земельної ділянки можуть бути визначені 3 точністю до 0,01 м? Таку точність можна отримати навіть не всіма модифікаціями GNSS-приймачів. Якшо ж координати точок кутів поворотів межі земельної ділянки округляти до $0,01 \mathrm{~m}$, то це призведе до того, шо за повторного обчислення плоші та довжин сторін цієї земельної ділянки їхні значення вілрізнятимуться від первинних [Рябчий В. А., Рябчий В. В., 2003].

Відповідно до пункту 3.10 Інструкції [Інструкція, 2010] середня квалратична похибка місцерозташування межового знака відносно найближчих пунктів державної геодезичної мережі, геодезичних мереж згушення, міських геодезичних мереж не повинна перевипувати:

- у Кисві, Севастополі, містах - обласних центрах та містах обласного підпорядкування $0,1 \mathrm{M}$;

- в інших містах та селишах - 0,2 м;

- у селах - 0,3 м;

- за межами населених пунктів для земельних ділянок плошею до 10 га $-0,5$ м, а плошею 10 га і більше - 2,5 м.

Вказані значення середніх квадратичних похибок положення кутів поворотів меж земельних ділянок характеризують допустимі величини похибок відносно пунктів державної геодезичної мережі, геодезичних мереж згущення, міських геодезичних мереж, а не відносно пунктів знімальної мережі. Але, як можна одержати середні квалратичні похибки поло- 
ження кутів поворотів $0,1 \mathrm{~m}$, якшо інструктивна точність знімальної планової мережі також становить $0,1 \mathrm{м}$ ?

Згідно 3 пунктом 5 Керівництва [Section 1, 2008] точність (розбіжність) положення геодезичних пунктів під час визначення їхніх координат за результатами повторних геодезичних вимірів відносно картографічної сітки Австралії не повинна перевишувати:

- у центральній частині міста - 0,02 м;

- комерційна і житлова забудова у межах міста - 0,03 м;

- інша забудова у межах міста - 0,05 м;

- землі сільськогосподарського призначення $-0,15$ м.

У той самий час відповідно до пункту 13.4 Керівництва [Section 13, 2014] рекомендують ймовірну похибку положення кутів поворотів (довірча ймовірність $50 \%$ ) під час виконання каластрових знімань не повинна перевипувати:

- у центральній частині міста -0,008 м;

- комерційна i житлова забудова у межах міста - 0,012 м;

- інша забудова у межах міста - 0,020 м;

- землі сільськогосподарського призначення $-0,060$ м.

Відповілно до Стандарту [Standards and Guidelines, 2001] точність визначення координат точок кутів поворотів меж земельної ділянки відносно найближчих кутів поворотів (похибка взасмного положення) не повинна перевишувати 0,05 м під час контролю виконання проектів землеустрою і 0,10 м - під час виконанні каластрових знімань. Відносно найближчих пунктів геодезичної мережі точність визначення координат точок кутів поворотів меж земельної ділянки не повинна перевипувати 0,10 м у разі контролю виконання проектів землеустрою і 0,20 м - під час виконання кадастрових знімань. Також значення допуску кадастрових вимірів у 0,086 м отримують із стандартної похибки поширення зв'язків. Воно засноване на такій формулі: квалратний корінь 3 суми квалратів допуску кадастрових вимірів $(0,086$ м) і максимально допустимої похибки контролю виконання проектів землеустрою $(0,05$ м), шо повинно приблизно дорівнювати максимально допустимій похибці кадастрових вимірювань $(0,10 \mathrm{M})$.

Тобто закордонні стандарти також наводять різну точність під час виконання робіт 3 топографічного знімання і координування кутів поворотів меж земельних ділянок. Також необхілно зауважити, шо ці стандарти $\epsilon$ більш “жорсткими”, шо пояснюється великою вартістю землі у цих країнах.

\section{Результати}

Після виконання геодезичних вимірів виконується їх математична обробка. Переважно вирівнювання усіх цих вимірів виконусться без урахування похибок вихілних пунктів та точок теодолітного ходу. Взагалі вважається, шо величини похибок вихідних пунктів значно менші, ніж похибки нижчого класу вимірів, тому їх можна не враховувати. Але у вказаній посліловності геодезичних робіт допускається два, а іноді і три випалки впливу похибок вихідних даних.

Перший випадок, коли не враховуються середні квалратичні похибки пунктів мереж згушення під час обчислення середніх квалратичних похибок точок знімальної мережі (теодолітних ходів). Другий - коли не враховуються серелні квалратичні похибки точок теодолітного ходу під час обчислення середніх квалратичних похибок координат точок кутів поворотів меж земельних ділянок. I третій коли за основу для координування точок кутів поворотів земельних ділянок можуть братись точки висячого теодолітного ходу.

Так, не врахування похибок вихідних пунктів, може призвести до спотворення поправок у виміряні величини і завишення оцінки точності пунктів знімальної мережі i кутів поворотів меж земельних ділянок.

Враховуючи вимоги Інструкчіії [Інструкція, 1998], можна якісно виконати виміри $i$ побудувати топографічний план будь-якої земельної ділянки, на якій розташовані якісь будівлі чи споруди. Потім можна виконати геодезичне встановлення меж пісї земельної ділянки, але може статись така ситуапія.

Межа земельної ділянки проходить по жорстких контурах (стіна, паркан тошо). Середня квалратична похибка положення цих контурів на топографічному плані може сягати 0,25 м, а середня квалратична похибка визначення координат точок кутів поворотів цієі межі не повинна перевишувати 0,1 м. Так, накреслена на топографічному плані межа такої земельної ділянки може не збігатись 3 відповідними 
контурами будівель чи споруд i “різати” їх. У територіальному органі Державного земельного агентства на це обов'язково звернуть увагу, i можуть повернути відповідну документапію із землеустрою на доопрацювання.

У таких випалках пропонується таке. Якшю на топографічному плані масштабу 1:500 межа земельної ділянки не збігається 3 контурами відповідних будівель чи споруд на величину до 1,0 мм, то необхілно провести цю межу по контурах відповідних будівель чи споруд. Якшо ця величина більше ніж 1,0 мм у масштабі плану, то необхідно з'ясувати причину цього, $\mathrm{i}$ відкоригувати топографічний план. У вілповідній пояснювальній записці необхідно це зазначити. Допустиме значення 1,0 мм взято, як подвосна середня квалратична похибка положення контурів на топографічному плані (підпункт 1.1.19 Інструкпії [Інструкпія, 1998]).

Враховувати середні квадратичні похибки пунктів державної геодезичної мережі та геодезичних мереж згушення, які використовуються як вихідні для побудови знімальної основи, практично неможливо, оскільки переважно таких даних у геофондах міста немас через об'сктивні причини. Хоча вирівнювання цих мереж виконувалось строгим способом, але до 90 років минулого століття існувала практика обчислювати серелню квалратичну похибку тільки найслабшої сторони або слабкого пункту. Сьогодні розвиток обчислювальної техніки i програмного забезпечення дає змогу враховувати середні квадратичні похибки вихілних пунктів, і це необхідно виконувати.

\section{Наукова новизна та практична значушість}

На похибку визначення положення або координат точок кутів поворотів межі земельної ділянки впливатимуть похибки положення або координат точок планової знімальної мережі i похибки координування точок кутів поворотів земельних ділянок. Це говорить про те, шо точність планової знімальної мережі під час виконання деяких робіт із землеустрою геодезичному встановленні або відновленні меж земельних ділянок - повинна бути вишою, ніж вказано в Інструктії [Інструкиія, 1998].

Під час вирівнювання результатів геодезичних вимірів 3 координування точок кутів поворотів меж земельних ділянок також необхілно враховувати серелні квалратичні похибки точок теодолітних ходів. Тому вико- ристовувати пункти планової знімальної мережі тахеометричного знімання для геодезичного встановлення або відновлення меж земельних ділянок не можна.

Звісно, координати планової знімальної мережі можна отримувати застосовуючи різні способи. Але враховуючи ситуацію у містах (забудова, рослинність тошо), найбільш рапіональними способами $\epsilon$ визначення координат точок знімальної мережі шляхом прокладання теодолітних ходів або шляхом комбінування прокладання теодолітного ходу i визначення координат точок за допомогою GNSS-приймачів.

Аналізуючи усі вимоги Інструкції [Інструкція, 1998] щодо точності знімальної мережі лля топографічного знімання та побудови топографічних планів масштабу 1:500, можна припустити, шо на сучасному рівні вони відповідають вирішенню вказаних задач. Але використовувати таку знімальну мережу для геодезичного встановлення або вілновлення меж земельних ділянок не рекомендується. Водночас створювати дві знімальні мережі окремо для виконання топографічного знімання та встановлення або відновлення меж земельних ділянок також не доцільно.

Автори виконали багато розрахунків точності побудови знімальної мережі та координат точок кутів поворотів меж земельних ділянок. Але враховуючи обсяг статті i безліч різних ситуаційних умов, ці приклали не можна вважати характерними. Оскільки одержані результати, крім точності геодезичних приладів $\mathrm{i}$ похибок вихідних пунктів, залежать від кількості точок, довжин сторін, форми та інших показників теодолітного ходу, а також плоші і конфігурапії земельної ділянки, то вони значно відрізняються. Тому наводимо тільки загальні висновки i пропонусмо таку послідовність вирішення порушеної проблеми, шо дас можливість створювати одну планову знімальну основу. Це дас змогу вирішити питання виконання робіт вілповідно до інструктивних вимог шодо точності визначення кутів поворотів меж земельних ділянок $\mathrm{i}$ пілвицити точність нанесення на топографічний план елементів ситуапії.

\section{Висновки та пропозиції}

На основі наведеного више можна зробити такі висновки та пропозицііі.

1. Створену за вимогами Інструктії з топографічного знімання у масштабах 1:5000, 
1:2000, 1:1000, 1:500 [Інструкція, 1998] знімальну мережу топографічного знімання у масштабі 1:500 використовувати для встановлення або відновлення меж земельних ділянок не доцільно. Оскільки така знімальна мережа не може забезпечити точність визначення положення точок кутів поворотів відповідно до вимог нормативно-правових актів України [Інструкція, 2010 i Порядок, 2012] та нормативного документа [Керівний технічний матеріал, 1993].

2. Пропонусться оновити Інструкпію 3 топографічного знімання у масштабах 1:5000, 1:2000, 1:1000, 1:500 [Інструкція, 1998] і увідповіднити іiі вимогам нормативно-правових актів України [Інструкція, 2010 і Порядок, 2012].

3. До виконання попереднього пункту:

3.1. Під час побудови знімальної мережі для геодезичного встановлення або відновлення меж земельної ділянки висячі теодолітні ходи повинні бути тільки у крайніх випадках. Кількість сторін висячого теодолітного ходу не повинна перевишувати двох, а його довжина відповідати вимогам підпункту 5.1 .7 (табл. 12) Інструкції [Інструкція, 1998].

3.2. Якшо для тієї самої земельної ділянки треба виконати топографічне знімання та встановлення або відновлення іiі меж, то необхідно створювати одну планову знімальну мережу такої точності, шоб забезпечити відповідні вимоги нормативно-правових актів України [Інструкпія, 2010 і Порядок, 2012] шодо точності встановлення або відновлення меж земельних ділянок.

3.3. Для виконання попереднього висновку необхідно обстежити територію земельної ділянки, обрати місця закладання пунктів знімальної мережі, виконати попередній розрахунок точності і запланувати відповідну методику геодезичних вимірів. Попередній розрахунок точності необхілно виконувати тільки строгим способом з урахуванням середніх квадратичних похибок усіх відповідних вихідних пунктів за допомогою сучасного програмного забезпечення та обчислювальної техніки.

Перспектива подальших досліджень полягає у визначенні реально можливої точності визначення положення кутів поворотів меж частин земельної ділянки, які містять обтяження та обмеження шодо використання землі.

\section{СПИСОК ВИКОРИСТАНИХ ДЖЕРЕЛ}

Брынь М. О. О параметрах кадастровой съемки городских объектов недвижимости / М. Брынь, П. Веселкин, В. Калгунов // Сучасні досягнення геодезичної науки та виробництва : зб. наук. пр. Зах. геодез. т-ва УТГК. - Л. : Вид-во Львів. політехніки, 2011. - Вип. I (21). - С. 271-272.

Дешевая Д. А. Обоснование точности измерений углов и длин при определении координат углов поворотов границ земельного участка полярным способом / Д. А. Дешевая, В. В. Рябчій // Сборник научных трудов Международного форум-конкурса молодых ученых “Проблемы недропользования". - СПб., 24-26 апреля 2013 г. - Ч. 1. - С. 152-154.

Доскоч А. Точність визначення плош за плоскими прямокутними координатами / А. Доскоч, В. Тарнавський, В. Літинський // Сучасні досягнення геодезичної науки та виробництва : зб. наук. пр. Зах. геодез. т-ва УТГК. - Л. : Вид-во Львів. політехніки, 2010. - Вип. I (19). - С. 107-114.

Дутчин М. Дослідження точності побудови планових знімальних мереж при інвентаризації земель населених пунктів / М. Дутчин, Т. Грицюк, І. Біда, М. Ничвид // Сучасні досягнення геодезичної науки та виробництва : зб. наук. пр. Зах. геодез. т-ва УТГК. - Л. : Вид-во Львів. політехніки, 2015. Вип. I (29). - С. 53-56.

Дутчин М. Дослідження точності побудови планових знімальних мереж при інвентаризації земель населених пунктів / М. М. Дутчин, Т. Ю. Грицюк, С. Ю. Ільків, I. В. Біда // Наук. вісник Ужгород. Ун-ту. Серія Географія. Землеустрій. Природокористування. - 2014. - Вип. 3. C. $48-53$.

Інструкція 3 топографічного знімання у масштабах 1:5000, 1:2000, 1:1000, 1:500 (ГКНТА-2.04-02-98), затверджена наказом Головного управління геодезії, картографії та кадастру при Кабінеті Міністрів України від 09.04.1998 р. № 56 із змінами, внесеними згідно 3 наказом Укргеодезкартографії від 27.07.1999 № 90. - К., 1999. - 156 c.

Інструкція про встановлення (відновлення) меж земельних ділянок в натурі (на місцевості) та їх закріплення межовими знаками, затверджена наказом Державного комітету України із земельних ресурсів від 18.05 .2010 р. № 376 iз змінами, внесеними згідно 3 наказом Міністерства аграрної політики та продовольства України від 03.07.2013 р. № 405.

Керівний технічний матеріал “Інвентаризація земель населених пунктів (наземні методи)", затверджений наказом Головного управління геодезії, картографії та кадастру при Кабінеті Міністрів України від 02.02.1993р. № 6. - Київ, 1993.

Островський А. Л. Методи визначення допустимих параметрів геодезичної основи великомасштабного топографічного знімання / А. Л. Островсь- 
кий, О. І. Мороз, В. Л. Тарнавський // Вісник геодезії та картографії. - 2007. - № 6 (51). - С. 7-15.

Порядок проведення інвентаризації земель, затверджений постановою Кабінету Міністрів України від 23.05.2012 p. № 513 із змінами, внесеними згідно 3 постановою Кабінету Міністрів України від 20.02.2013 р. № 154.

Рябчий В. А. Влияние ошибок округления координат углов поворотов границ земельных участков на точность определения их площадей / В. А. Рябчий, В. В. Рябчий // Інженерна геодезія. - 2003. Вип. 49. - С. 193-201.

Рябчій В. А. Встановлення точності визначення площ земельних ділянок під малими об'єктами нерухомості / В. А. Рябчій, В. В. Рябчій, О. С. Янкін // Сучасні досягнення геодезичної науки та виробництва : зб. наук. пр. - Л., 2010. Вип. II (20). C. 204-208.

Рябчій В. А. Реконструкція геодезичних мереж міст / В. А. Рябчій, В. В. Рябчій // Сучасні досягнення

\section{В. В. РЯБЧИЙ}

Кафедра геодезии, Национальный университет “Львовская политехника”, ул. С. Бандеры, 12, Львов, Украина, 79013; тел.: +38(056)3730720; эл. почта: RyabchyV @ nmu.org.ua

\section{О ПРИМЕНЕНИИ СЪЕМОЧНОЙ СЕТИ ДЛЯ ГЕОДЕЗИЧЕСКОГО УСТАНОВЛЕНИЯ ГРАНИЦ ЗЕМЕЛЬНОГО УЧАСТКА}

Цель. Разработка документации по землеустройству по отводу земельных участков в населенных пунктах Украины являются наиболее распространенным и востребованным видом работ по землеустройству. Для качественного их выполнения при проектировании границ земельного участка в городах на современном уровне необходимо пользоваться актуальными топографическими планами масштаба 1:500. Для выполнения тахеометрической съемки и геодезического установления (восстановления) границ земельного участка создается съемочная основа. При этом промежуток времени между двумя видами этих работ оказывается незначительным. Также эти работы могут осуществляться одновременно, если отвод земельного участка выполняется по фактическому размещению зданий, сооружений, заборов и т.п. Тахеометрическая съемка и геодезическое установление границ выполняется согласно с соответствующими инструкциями. Очевидно, что было бы рационально созданную плановую съемочную сеть для тахеометрической съемки использовать и для геодезического установления границ земельного участка. Таким образом, возникает задача создать одну плановую съемочную сеть, которая бы отвечала требованиям к точности действующих инструкций по выполнению указанных работ. Методика. Для решения приведенной цели выполнен анализ и сравнение требований всех действующих инструкций по точности построения съемочных сетей тахеометрической съемки и инструкций по установлению (восстановлению) границ земельных участков в натуре (на местности). Также проанализированы публикации ученых нашей и других стран по этой проблеме. Систематизированы требования к точности проложения теодолитных ходов, построений на топографических планах жестких контуров, зданий, сооружений (наземных и подземных инженерных коммуникаций, что особенно важно в тех местах, где имеется плотная застройка). Результаты. На основе анализа нормативноправовых актов Украины определено, что для тахеометрической съемки допускается упрощенное выравнивания теодолитных ходов без учета погрешностей исходных пунктов. Также допускается висячие теодолитные ходы до четырех сторон. При этом ничего не говорится об высчислении средней квадратичной погрешности точек висячего теодолитного хода и учета средних квадратичных погрешностей точек основного теодолитного хода. Также установлено, что съемочное обоснование для тахеометрической съемки неуместно и, вообще, нельзя использовать для геодезического установления (координации) углов поворотов границ земельного участка, поскольку не дает возможности определить координаты точек углов поворотов границ этих земельных участков с точностью, регламентированой действующими нормативно правовыми актами Украины. Научная новизна. По результатам выполненных исследований современного состояния затронутой проблемы разработаны предложения по последовательности ее решения. Предложенный для использования классический метод предварительного расчета точности элементов геодезических сетей “частично забыт” и дает возможность индивидуального подхода к разработке методики измерений в каждом 
случае совместного или отдельного выполнения работ по тахеометрической съемке земельного участка и геодезического установление его границ. Практическая значимость работы заключается в том, что для двух видов работ таких будет создаваться одна плановая съемочная основа. В результате этого координаты точек углов поворотов границ земельного участка и соответственно его плошадь будут высчисляться с точностью, соответствуюшей действуюшим инструкциям, а в случае необходимости еше точнее.

Ключевые слова: съемочная сеть; теодолитный ход; тахеометрическая съемка; геодезическое установление границ земельного участка; точность определения координат.

\section{V. RIABCHII}

Department of Geodesy, Lviv PolytechnicNational University, S. Bandery str., 12, Lviv, Ukraine, 79013, tel.: +38(056)3730720, +38(0562)472411; e-mail: RyabchyV@nmu.org.ua

\section{ON THE USE OF THE SET OF GEODETIC NETWORKS FOR THE SURVEYING OF LAND BOUNDARIES}

Aim. Development of land use on land allocation in settlements of Ukraine is the most common and popular types of work on land management. For quality of their performance in the design of the boundaries of land in urban areas to date need to use the actual topographical plans scale 1:500. To perform tacheometric removal and installation of the geodesic (renewal) boundaries of land created by film basis. Thus, the interval between the two types of minor works. Also, this work may be performed simultaneously if land allocation performed by the actual placing of buildings, fences and more. Tacheometric removal and geodetic delineation performed according to instructions. Obviously, that would be established rationally planned filming network for removal tacheometric used for surveying delineating land. Thus, there is a problem of a routine imaging network that would meet the requirements for accuracy of operating instructions for the implementation of these activities. Methods. To address the reduced goal the analysis and comparison of the requirements of all applicable instructions for the accuracy of building networks tacheometric film removal and installation instructions (recovery) of land boundaries in nature (on ground). Also reviewed publication of our scientists and other states on this issue. Systematized requirements for accuracy laying theodolite moves, building on topographic plans harsh contours, buildings, structures (surface and underground utilities, which is especially important in urban areas, where the built up areas of their large number). Results. Based on analysis of legal acts of Ukraine stipulates that tacheometric removal may be simplified leveling theodolite moves, excluding errors starting point. It also enables hanging theodolite moves to four. However, nothing is said about the calculation of the mean square error of hanging traverse points and taking into account the mean square errors of the main points traverse. Also found that crew tacheometric basis for removal of inappropriate and, in general, can not be used for surveying installation (coordinate) rotation angles boundaries of the land, as it makes it impossible to determine the coordinates of corners of turns boundaries of land with a precision that is regulated by the applicable regulatory acts of Ukraine. Scientific novelty. As a result of the current state of the research problems raised proposals on the sequence of its decision. Proposed to use "partly forgotten", the classic method of calculating precision geodetic network elements, enables an individual approach to the development of measurement techniques in each case common or individual works on tacheometric removal of land surveying and setting its limits. The practical significance The practical significance of the work lies in the fact that two types of jobs will be created a film scheduled basis. As a result, coordinates turns corners and boundaries of land under its area will be calculated with an accuracy that meets current guidelines and, if necessary, more precisely.

Keywords: survey network; theodolite traverse; tacheometric removal; geodetic delineating land; accuracy of the coordinates.

\section{REFERENCES}

Bryn’ M. O., Veselkin P., Kalgunov V. O parametrah kadastrovoj s\#emki gorodskih ob\#ektov nedvizhimosti [On the parameters of urban cadastral survey of real estate]. Suchasni dosiahnennia heodezychnoi nauky ta vyrobnytstva: zb. nauk. pr. Zakh. heodez. t-va UTHK. [Modern achievements in geodetic science and industry]. Vyd-vo Lviv. Politekhniky [Lviv Polytechnic Publishing House]. Lviv, 2011, issue I (21), pp. 271-272.

Deshevaja D. A, Rjabchij V. V. Obosnovanie tochnosti izmerenij uglov $i$ dlin pri opredelenii koordinat uglov povorotov granic zemel'nogo uchastka poljarnym sposobom [Substantiation of the accuracy of measurements of angles and lengths in determining the coordinates of the corners of turns of land borders the Arctic way]. Sbornik nauchnyh trudov Mezhdunarodnogo forum-konkursa molodyh uchenyh "Problemy nedropol'zovanija" [Collection of scientific works of the International Forum of Young Scientists Contest "Problems of subsoil use"]. St. Petersburg, April 24-26, 2013, Part 1, pp. 152-154.

Doskoch A., Tarnavskyi V., Litynskyi V. Tochnist vyznachennia ploshch za ploskymy priamokutnymy koordynatamy [The accuracy of space at flat rectangular coordinates]. Suchasni dosiahnennia heodezychnoi nauky ta vyrobnytstva: zb. nauk. pr. Zakh. heodez. t-va UTHK. [Modern achievements in geodetic science and industry]. L.: Vyd-vo Lviv. Politekhniky [Lviv Polytechnic Publishing House]. 2010, issue I (19), pp. 107-114. 
Dutchyn M., Hrytsiuk T., Bida I., Nychvyd M. Doslidzhennia tochnosti pobudovy planovykh znimalnykh merezh pry inventaryzatsii zemel naselenykh punktiv [Research of accuracy constructing planned of surveying networks in inventory of land settlements]. Suchasni dosiahnennia heodezychnoi nauky ta vyrobnytstva: zb. nauk. pr. Zakh. heodez. t-va UTHK. [Modern achievements in geodetic science and industry]. L.: Vyd-vo Lviv. Politekhniky [Lviv Polytechnic Publishing House], 2015, issue I (29), pp. 53-56.

Dutchyn M., Hrytsiuk T.Yu., Ilkiv Ye.Yu., Bida I.V. Doslidzhennia tochnosti pobudovy planovykh znimalnykh merezh pry inventaryzatsii zemel naselenykh punktiv [Research of accuracy constructing planned of surveying networks in inventory of land settlements]. Naukovyi visnyk Uzhhorodskoho universytetu. Seriia Heohrafiia. Zemleustrii. Pryrodokorystuvannia [Scientific Bulletin of the Uzhgorod University. Series Geography. Land Management. Nature]. 2014, issue 3, pp. 48-53.

Instruktsiia z topohrafichnoho znimannia u masshtabakh 1:5000, 1:2000, 1:1000, 1:500 (HKNTA-2.04-02-98) [Instruction of topographic removal in the scale of 1: 5000, 1: 2000, 1: 1000, 1: 500 (HKNTA-2.04-02-98)]. zatverdzhena nakazom Holovnoho upravlinnia heodezii, kartohrafii ta kadastru pry Kabineti Ministriv Ukrainy vid 09.04.1998 \# 56 iz zminamy, vnesenymy zghidno z nakazom Ukrheodezkartohrafii vid 27.07.1999 \# 90 [approved by the Main Department of Geodesy, Cartography and Cadastre at the Cabinet of Ministers of Ukraine dated 09.04.1998, no. 56 as amended according to the order Ukrheodezkartohrafiyi of 27.07.1999, no. 90]. Kyiv, 1999, 156 p.

Instruktsiia pro vstanovlennia (vidnovlennia) mezh zemelnykh dilianok v naturi (na mistsevosti) ta yikh zakriplennia mezhovymy znakamy [Instructions on installation (recovery) of land boundaries in nature (on ground) and their consolidation boundary marks] zatverdzhena nakazom Derzhavnoho komitetu Ukrainy iz zemelnykh resursiv vid 18.05.2010 \# 376 iz zminamy, vnesenymy zghidno z nakazom Ministerstva ahrarnoi polityky ta prodovolstva Ukrainy vid 03.07.2013 \# 405 [approved by the State Committee for Land Resources of Ukraine of 18.05.2010, no. 376 as amended in accordance with the order of the Ministry of Agrarian Policy and Food of Ukraine] 03.07.2013, no. 405

Kerivnyi tekhnichnyi material "Inventaryzatsiia zemel naselenykh punktiv (nazemni metody)" [The governing technical material "Inventory of land settlements (ground techniques)"], zatverdzhenyi nakazom Holovnoho upravlinnia heodezii, kartohrafii ta kadastru pry Kabineti Ministriv Ukrainy vid 02.02.1993 \# 6 [approved by the Main Department of Geodesy, Cartography and Cadastre at the Cabinet of Ministers of Ukraine] dated 02.02.1993, no. 6, Kyiv, 1993.

Ostrovskyi A. L., Moroz O. I., Tarnavskyi V. L. Metody vyznachennia dopustymykh parametriv heodezychnoi osnovy velykomasshtabnoho topohrafichnoho znimannia [Methods for determining acceptable parameters geodesic basis of large-scale of topographic removal]. Visnyk heodezii ta kartohrafii [Journal of Geodesy and Cartography]. 2007, no. 6 (51), pp. 7-15.

Poriadok provedennia inventaryzatsii zemel, zatverdzhenyi postanovoiu Kabinetu Ministriv Ukrainy vid 23.05.2012 \# 513 [The order of an inventory of land, approved by the Cabinet of Ministers of Ukraine dated 23.05.2012 № 513] iz zminamy, vnesenymy zghidno z postanovoiu Kabinetu Ministriv Ukrainy vid 20.02.2013 \# 154 [as amended in accordance with the Cabinet of Ministers of Ukraine] of 20.02.2013, no. 154.

Rjabchij V. A., Rjabchij V. V. Vlijanie oshibok okruglenija koordinat uglov povorotov granic zemel'nyh uchastkov na tochnost' opredelenija ih ploshhadej [The impact of rounding errors coordinate angle bends the boundaries of land on the accuracy of the determination of their areas]. Inzhenerna heodeziia [Engineering geodesy]. 2003, issue 49, pp. 193-201.

Riabchii V. A., Riabchii V. V., Yankin O. Ye. Vstanovlennia tochnosti vyznachennia ploshch zemelnykh dilianok pid malymy obiektamy nerukhomosti [Installing the accuracy of the areas of land for small objects of real estate]

Suchasni dosiahnennia heodezychnoi nauky ta vyrobnytstva. Zb. nauk. Prats [Modern achievements in geodetic science and industry. Coll. Science. Works]. Lviv, 2010, Vol. II (20), pp. 204-208.

Riabchii V. A., Riabchii V. V. Rekonstruktsiia heodezychnykh merezh mist [Reconstruction of geodetic networks of cities]. Suchasni dosiahnennia heodezychnoi nauky ta vyrobnytstva. Zb. nauk. Prats [Modern achievements in geodetic science and industry. Coll. Science. Works]. Lviv, 2005, Vol. II, pp. 49-53.

Trevoho I., Riabchii V. Rekonstruktsiia heodezychnykh merezh velykykh mist Ukrainy [Reconstruction of geodetic networks in big cities of Ukraine]. Naukovyi visnyk Uzhhorodskoho universytetu. Seriia Heohrafiia. Zemleustrii. Pryrodokorystuvannia [Scientific Bulletin of the Uzhgorod University. Series Geography. Land Management. Nature]. 2014. Vol. 3, pp. 12-18.

Craig Belle A. and Wahl Jerry L. Cadastral Survey Accuracy Standards. Surveying and Land Information Science. 2003, Vol. 63, no. 2, pp. 87-106.

Section 1. Introduction and Surveyor-General's directions. Cadastral Surveys Guidelines. Issue 6, January 2008.

Section 13. Survey Accuracies. Cadastral Surveys Guidelines. Issue 3.2, July 2014.

Standards and Guidelines for Cadastral Surveys Using Global Positioning System Methods. United State Department of Agriculture (Forest Service) and United State Department of Interior (Bureau of Land Management). Ver. 1.0. 09.05.2001, $19 \mathrm{p}$.

Надійшпла 04.11.2015 p. 